\title{
Virgibacillus chiguensis sp. nov., a novel halophilic bacterium isolated from Chigu, a previously commercial saltern located in southern Taiwan
}

Correspondence

Yuan-Tay Shyu

tedshyu@ntu.edu.tw

\author{
Chung-Yi Wang, ${ }^{1}$ Chen-Chin Chang, ${ }^{2}$ Chang Chai Ng, ${ }^{1}$ Tseng-Wei Chen ${ }^{1}$ \\ and Yuan-Tay Shyu ${ }^{1}$
}

\author{
${ }^{1}$ Department of Horticulture, National Taiwan University, 140 Keelung Road Section 4, Taipei 106, \\ Taiwan, ROC \\ ${ }^{2}$ Department of Home Economics, Tainan University of Technology, 529 Jhongjheng Road, \\ Yongkang, Tainan 71002, Taiwan, ROC
}

\begin{abstract}
A Gram-positive, motile, endospore-forming, irregular rod-shaped (0.7-0.9 $\times 2.5-5.0 \mu \mathrm{m})$, halophilic bacterial strain, NTU-101 ${ }^{\top}$, was isolated from Chigu saltern in southern Taiwan, previously used as a salt production field. The isolate was characterized taxonomically based on biochemical and molecular approaches. It grows optimally at $40{ }^{\circ} \mathrm{C}$ and in the presence of 5$10 \% \mathrm{NaCl}$. Strain NTU-101 ${ }^{\top}$ has cell-wall peptidoglycan based on meso-diaminopimelic acid and MK-7 as the predominant menaquinone. Major polar lipids are phosphatidylglycerol, diphosphatidylglycerol and phosphatidylethanolamine. Anteiso- $C_{15: 0}$, iso- $C_{15: 0}$ and anteiso$\mathrm{C}_{17: 0}$ are the major fatty acids. The DNA G+C content was $37.3 \mathrm{~mol} \%$. Phylogenetic analyses based on 16S rRNA gene sequences showed its affiliation to the genus Virgibacillus. DNA-DNA relatedness values between strain NTU $-101^{\top}$ and Virgibacillus dokdonensis and Virgibacillus pantothenticus were 17.5 and $21.5 \%$, respectively. Based on the phenotypic and phylogenetic properties, strain NTU-101 ${ }^{\top}\left(=\right.$ BCRC $17637^{\top}=$ CGMCC $\left.1.6496^{\top}\right)$ was classified as a novel strain of Virgibacillus species, for which the name Virgibacillus chiguensis sp. nov. is proposed.
\end{abstract}

The genus Virgibacillus was first proposed by Heyndrickx et al. in 1998. At the time of writing, 12 species have been validly described: Virgibacillus pantothenticus (Heyndrickx et al., 1998), Virgibacillus proomii (Heyndrickx et al., 1999), Virgibacillus carmonensis, Virgibacillus necropolis, Virgibacillus picturae (Heyrman et al., 2003), Virgibacillus marismortui, Virgibacillus salexigens (Heyrman et al., 2003), Virgibacillus halodenitrificans (Yoon et al., 2004), Virgibacillus dokdonensis (Yoon et al., 2005), Virgibacillus koreensis (Lee et al., 2006), Virgibacillus olivae (Quesada et al., 2007) and Virgibacillus halophilus (An et al., 2007). In this study, a morphological, biochemical and phylogenetic characterization of a halophilic Virgibacillus-like strain, NTU- $101^{\mathrm{T}}$, was carried out. A single isolate of strain NTU$101^{\mathrm{T}}$ was obtained from soil sediment collected from Chigu saltern, southern Taiwan. The isolate was cultured using a standard dilution method. Briefly, soil sediment was dissolved in distilled water, diluted 1:1 with solutions of $5,10,15$ and $20 \%(\mathrm{w} / \mathrm{v}) \mathrm{NaCl}$ and plated onto modified DSM 372 agar plates. The agar plate $\mathrm{pH}$ was adjusted to 7.0 with $1 \mathrm{M} \mathrm{KOH}$. The plates were then incubated at $37{ }^{\circ} \mathrm{C}$ for 7 days. Single colonies with different morphology were

The GenBank/EMBL/DDBJ accession number for the 16S rRNA gene sequence of strain NTU $-101^{\top}$ is EF 101168. selected for growth tests. The salt requirement of the isolates was tested using DSM 372 medium $\left[\mathrm{g} \mathrm{l}^{-1}\right.$ : yeast extract (Difco), 5; Casamino acids (Difco), 5; $\mathrm{MgSO}_{4} \cdot 7 \mathrm{H}_{2} \mathrm{O}$, 5; tri-sodium citrate (Sigma), 3; KCl, 2] containing $5 \%(\mathrm{w} / \mathrm{v}) \mathrm{NaCl}$. Growth was also measured at various temperatures $\left(10-70{ }^{\circ} \mathrm{C}\right), \mathrm{pH}$ values $(4-10)$ and salt concentrations $(0-35 \%)$. The growth rate was monitored by spectrophotometry at $660 \mathrm{~nm}$. The Gram reaction was tested using a Gram stain kit (Becton Dickinson), according to the manufacturer's instructions. Physiological characterization was carried out by measuring substrate utilization or oxidation reactions on different carbohydrate sources and amino acids using a GN2 MicroPlate Identification Test panel (Biolog). Enzyme activity was determined using the API ZYM system (bioMérieux). Morphology was studied by scanning electron microscopy (SEM), The sample was fixed and processed according to the recommended procedure for specimen preparation (Anton et al., 2002). Gold (approx. thickness $5 \mathrm{~nm}$ ) was used to coat the samples prior to examination with a scanning electron microscope (Topcon).

Using SEM, strain NTU-101 ${ }^{\mathrm{T}}$ was observed to be rodshaped. Cultural, physiological and biochemical properties are shown in Table 1. Growth tests with different 
Table 1. Differential phenotypic characteristics of $\mathrm{NTU}-101^{\top}$ and other Virgibacillus species

Taxa: 1, NTU-101 ${ }^{\mathrm{T}}$; 2, V. pantothenticus; 3, V. dokdonensis; 4, V. proomii; 5, V. marismortui; 6, V. carmonensis; 7, V. necropolis; 8, V. picturae; 9, V. halodenitrificans (Yoon et al., 2005); 10, V. olivae (Quesada et al., 2007); 11, V. halophilus (An et al., 2007). +, Positive; -, negative; W, weakly positive; ND, no data available; v, variable; E, ellipsoidal; S, spherical; C, central; ST, subterminal; T, terminal; PG, phosphatidylglycerol; DPG, diphosphatidylglycerol; PE, phosphatidylethanolamine; PLs, unidentified phospholipids; APL, unknown aminophospholipid; tr, trace.

\begin{tabular}{|c|c|c|c|c|c|c|c|c|c|c|c|}
\hline Characteristic & 1 & 2 & 3 & 4 & 5 & 6 & 7 & 8 & 9 & 10 & 11 \\
\hline Spore shape & $\mathrm{S}$ or $\mathrm{E}$ & $\mathrm{S}$ or $\mathrm{E}$ & $\mathrm{S}$ or $\mathrm{E}$ & $\mathrm{S}$ or $\mathrm{E}$ & E & E or $S$ & $\mathrm{E}$ & E & E & $\mathrm{S}$ or $\mathrm{E}$ & $\mathrm{E}$ \\
\hline Spore position & $\mathrm{T}$ or $\mathrm{ST}$ & $\mathrm{T}$ or $\mathrm{ST}$ & $\mathrm{T}$ or ST & $\mathrm{T}$ or $\mathrm{ST}$ & $\mathrm{T}$ or $\mathrm{ST}$ & ST & C, ST or T & C, ST or T & $\mathrm{T}$ or $\mathrm{ST}$ & $\mathrm{T}$ or $\mathrm{ST}$ & S \\
\hline Gram stain & + & + & $\mathrm{V}$ & + & + & + & + & + & $\mathrm{V}$ & + & + \\
\hline Pigmentation & - & - & - & - & - & Pink & - & - & - & Yellow & Yellow \\
\hline Anaerobic growth & + & + & + & + & - & - & - & - & + & - & - \\
\hline \multicolumn{12}{|l|}{ Growth at: } \\
\hline $0.5 \% \mathrm{NaCl}$ & + & $\mathrm{W}$ & + & $\mathrm{W}$ & - & - & $\mathrm{W}$ & - & $\mathrm{V}(-)$ & + & + \\
\hline $25 \% \mathrm{NaCl}$ & + & - & - & - & - & - & - & $\mathrm{W}$ & $\mathrm{v}(+)$ & - & - \\
\hline pH 10 & - & - & ND & - & - & ND & ND & ND & - & - & + \\
\hline $\begin{array}{l}\text { Temperature range } \\
\left({ }^{\circ} \mathrm{C}\right)\end{array}$ & $15-55$ & $15-50$ & $15-50$ & $15-50$ & $15-50$ & $10-40$ & $10-40$ & $15-45$ & $10-45$ & $20-45$ & $5-45$ \\
\hline Nitrate reduction & + & v & - & - & + & + & + & - & + & + & + \\
\hline $\mathrm{H}_{2} \mathrm{~S}$ production & - & $\mathrm{V}$ & - & - & + & - & - & + & - & ND & - \\
\hline \multicolumn{12}{|l|}{ Hydrolysis of: } \\
\hline Aesculin & + & + & + & + & + & $\mathrm{W}$ & - & + & $\mathrm{v}(-)$ & + & + \\
\hline Casein & + & + & + & + & + & + & + & + & + & + & ND \\
\hline Gelatin & + & + & + & v & + & - & $\mathrm{W}$ & + & + & + & + \\
\hline \multicolumn{12}{|l|}{ Growth on: } \\
\hline D-Glucose & + & $\mathrm{w}$ & + & $\mathrm{w}$ & - & - & + & $\mathrm{w}$ & + & - & ND \\
\hline D-Fructose & + & - & + & - & - & - & - & - & $\mathrm{v}(+)$ & + & ND \\
\hline Sucrose & + & - & + & + & + & + & + & + & + & - & ND \\
\hline \multicolumn{12}{|l|}{ Acid production from: } \\
\hline D-Galactose & + & - & + & + & - & - & - & $\mathrm{W}$ & + & - & $\mathrm{W}$ \\
\hline D-Glucose & + & - & + & + & + & - & $\mathrm{W}$ & W & + & - & + \\
\hline D-Fructose & + & - & + & + & + & - & $\mathrm{W}$ & $\mathrm{W}$ & + & + & + \\
\hline D-Mannose & + & - & + & + & + & - & $\mathrm{W}$ & $\mathrm{W}$ & + & - & + \\
\hline D-Melibiose & + & - & - & - & - & - & - & - & - & $\mathrm{ND}$ & - \\
\hline D-Rhammose & - & + & - & v & - & - & - & - & - & - & - \\
\hline D-Trehalose & - & + & - & + & - & - & $\mathrm{w}$ & - & + & $\mathrm{ND}$ & + \\
\hline D-Mannitol & W & - & - & - & - & - & - & - & $\mathrm{v}(+)$ & - & + \\
\hline Major polar lipids & $\begin{array}{r}\text { PG, DPG, } \\
\text { PE, PLs }\end{array}$ & $\begin{array}{l}\text { PG, DPG, } \\
\text { PE, PLs }\end{array}$ & $\begin{array}{r}\text { PG, DPG, } \\
\text { PE, PLs }\end{array}$ & $\begin{array}{l}\text { PG, DPG, } \\
\text { PE, PLs }\end{array}$ & $\begin{array}{l}\text { PG, DPG, } \\
\text { PLs }\end{array}$ & $\begin{array}{c}\text { PG, } \\
\text { DPG, } \\
\text { PE, PLs }\end{array}$ & PG, DPG, PL & $\begin{array}{l}\text { s PG, DPG, } \\
\text { PLs }\end{array}$ & $\begin{array}{l}\text { PG, DPG, } \\
\text { PLs }\end{array}$ & ND & $\mathrm{ND}$ \\
\hline Presence of APL & - & + & - & $\operatorname{tr}$ & $\operatorname{tr}$ & - & - & - & ND & ND & ND \\
\hline $\begin{array}{l}\text { DNA G + C content } \\
(\mathrm{mol} \%)\end{array}$ & 37.3 & $36.9-38.3$ & 36.7 & $36.8-37.0$ & $39.0-42.8$ & 38.9 & 37.3 & $39.5-40.0$ & $38-39$ & 33.4 & 42.6 \\
\hline
\end{tabular}

concentrations of $\mathrm{NaCl}$ indicated that strain $\mathrm{NTU}-101^{\mathrm{T}}$ was able to grow in the presence of up to $25 \% \mathrm{NaCl}$, whereas $V$. dokdonensis and $V$. pantothenticus are unable to survive under such conditions. Strain NTU- $101^{\mathrm{T}}$ and $V$. dokdonensis were able to produce acid from D-galactose, Dglucose, D-fructose, D-mannose and D-melibiose, whereas $V$. pantothenticus was not. An unidentified aminophospholipid found in $V$. dokdonensis and $V$. pantothenticus was not found in strain NTU-101 ${ }^{\mathrm{T}}$.

The $\mathrm{G}+\mathrm{C}$ content of the DNA was determined by the method of Mesbah et al. (1989). The nucleotide mixtures were separated by HPLC (JASCO) using a Phenomenex
C18 column. A flow rate of $1.0 \mathrm{ml} \mathrm{min}^{-1}$ at a temperature of $37^{\circ} \mathrm{C}$ was used and the DNA was quantified by measuring $A_{260}$. Non-methylated bacteriophage lambda DNA (Sigma) was used as the calibration reference. Fatty acid composition was represented by fatty acid methyl esters (FAMEs). Cultures were transferred onto Trypticase Soy Agar (TSA) plates containing 3\% Trypticase Soy Broth, $1.5 \%$ Bacto-Agar (Difco) and $7 \% \mathrm{NaCl}$ for $24 \mathrm{~h}$ at $37^{\circ} \mathrm{C}$. Single colonies were taken with a platinum inoculating loop and transferred to $10 \mathrm{ml}$ Teflon centrifuge tubes equipped with Teflon screw caps (Nalge Nunc International). The extraction of fatty acid was carried out as described by Heyrman et al. (1999). FAME profiles 
were obtained by GLC using a model $6890 \mathrm{~N}$ gas chromatograph (HP) as described by Descheemaeker \& Swings (1995). The resulting profiles were identified with microbial identification software (MIDI) and a standardized calibration mixture. The isomer of diaminopimelic acid in the peptidoglycan was determined by using the method of Komagata \& Suzuki (1987). The identity of the quinines was determined by HPLC (Shin et al., 1996). Analysis of polar lipids by two-dimensional TLC was performed as described by Komagata \& Suzuki (1987).

The majority of fatty acids detected in strain NTU-101 ${ }^{\mathrm{T}}$ were branched fatty acids $(87 \%)$; anteiso- $\mathrm{C}_{15: 0}$ and anteiso- $\mathrm{C}_{17: 0}$ were present at 52.9 and $15.9 \%$, respectively (Table 2). Other branched fatty acids present were iso$\mathrm{C}_{14: 0}(1.8 \%)$, iso- $\mathrm{C}_{15: 0}(12.1 \%)$, iso- $\mathrm{C}_{16: 0}(4.2 \%)$ and iso- $\mathrm{C}_{17: 0}(1.5 \%)$. Branched fatty acids comprise of 93 and $97.9 \%$ of total fatty acids in $V$. dokdonensis and $V$. pantothenticus, respectively. This indicates that strain NTU- $101^{\mathrm{T}}$ differs from $V$. dokdonensis and $V$. pantothenticus with respect to fatty acid composition. The major polar lipids were phosphatidylglycerol, diphosphatidylglycerol and phosphatidylethanolamine with some unidentified phospholipids. Strain NTU- $101^{\mathrm{T}}$ has cell-wall peptidoglycan based on meso-diaminopimelic acid, with MK-7 as the predominant menaquinone. This profile is similar to other members of the genus Virgibacillus.

Nucleic acids of isolates were extracted using the FastDNA Spin kit (Bio 101), according to the manufacturer's instructions. Two universal primers (9F and 1492R) were used for amplification of the 16S rRNA gene (Stackebrandt \& Liesack, 1993). The amplification was performed with the GeneAmp PCR system 9700 (Applied Biosystems). Amplicons were later sequenced (Mission Biotech) and aligned with representatives from genus Virgibacillus and related taxa using multiple sequence alignment software (ClUSTAL W 1.82; Thompson et al., 1994). A phylogenetic tree was constructed by the neighbour-joining and UPGMA methods with a bootstrap robustness of 1000 using PHYLIP package 3.6b.

The neighbour-joining tree based on the 16S rRNA gene sequence $(1465 \mathrm{nt})$ showed that strain NTU- $101^{\mathrm{T}}$ is most closely related to $V$. dokdonensis at a bootstrap level of $99.2 \%$. The remaining Virgibacillus species clustered within a clade (Fig. 1). Of particular note is the fact that strain $\mathrm{NTU}-101^{\mathrm{T}}$ is topologically distinct from $V$. koreensis, a novel bacterium discovered in a similar salt field environment (Lee et al., 2006). Phylogenetic trees based on maximum-likelihood and maximum-parsimony algorithms were also constructed, and although they demonstrated a slightly different tree topology, the relationships among the various species of Virgibacillus remained similar (data not shown). Strain NTU-101 ${ }^{\mathrm{T}}$ exhibited $16 \mathrm{~S}$ rRNA gene sequence similarity of 99.6 and $97.5 \%$ to $V$. dokdonensis and $V$. pantothenticus, respectively. DNADNA hybridization was performed fluorometrically by the method of Ezaki et al. (1989) and values of 17.5 and $21.5 \%$ were obtained for strain NTU-101 ${ }^{\mathrm{T}}$ with $V$. dokdonensis and $V$. pantothenticus, respectively.

Strain NTU- $101^{\mathrm{T}}$ grew in higher concentrations of $\mathrm{NaCl}$ (up to $30 \%$ ) than any previously described species of Virgibacillus. Acid production in strain NTU- $101^{\mathrm{T}}$ also varied compared to other species of Virgibacillus. Therefore, differences in terms of biochemical, physiological and phylogenetic relationships are sufficient to suggest that strain NTU- $101^{\mathrm{T}}$ is a novel species of the genus Virgibacillus, for which the name Virgibacillus chiguensis sp. nov. is proposed.

\section{Description of Virgibacillus chiguensis sp. nov.}

Virgibacillus chiguensis (chi.gu.en'sis. N.L. masc. adj. chiguensis of chigu, a disused salt production field in southern Taiwan from where the strain in this study was isolated).

Cells are rod-shaped, $0.7-0.9 \times 2.5-5.0 \mu \mathrm{m}$. Gram-positive and motile by means of peritrichous flagella. Terminal or subterminal spore position. Colonies are irregular to regular, flat and translucent, and milky white in colour. After $72 \mathrm{~h}$ incubation at $37{ }^{\circ} \mathrm{C}$ on DSM 372 agar with $10 \%$ $(\mathrm{w} / \mathrm{v}) \mathrm{NaCl}$, the colony diameter was $5-7 \mathrm{~mm}$. Growth occurs between 0 and $30 \% \mathrm{NaCl}$; optimal growth occurs at $5-10 \% \mathrm{NaCl}$. Optimal growth occurs at $40{ }^{\circ} \mathrm{C}$; growth was observed at $15-50{ }^{\circ} \mathrm{C}$, but not under $10{ }^{\circ} \mathrm{C}$. The $\mathrm{pH}$ range

Table 2. Percentage composition of major fatty acids in Virgibacillus chiguenesis sp. nov. and related Virgibacillus species

Species: 1, V. chigunensis sp. nov.; 2, V. dokdonensis (Yoon et al., 2005); 3, V. pantothenticus; 4, V. proomii; 5, V. marismortui; 6, V. carmonensis; 7, V. necropolis; 8, V. salexigens; 9, V. halodenitrificans (Lee et al., 2006); 10, V. olivae (Quesada et al., 2007); 11, V. halophilus (An et al., 2007). tr, Trace amount.

\begin{tabular}{|c|c|c|c|c|c|c|c|c|c|c|c|}
\hline Fatty acid & 1 & 2 & 3 & 4 & 5 & 6 & 7 & 8 & 9 & 10 & 11 \\
\hline Iso- $\mathrm{C}_{14: 0}$ & 1.8 & 4.7 & 2.3 & 2.4 & 2.8 & 3.3 & 2.2 & 2.4 & 7.4 & 2.0 & 5.6 \\
\hline Iso- $\mathrm{C}_{15: 0}$ & 12.1 & 19.4 & 7.1 & 15.1 & 39.0 & 5.7 & 3.8 & 15.1 & 2.3 & 33.7 & 21.2 \\
\hline Iso- $\mathrm{C}_{16: 0}$ & 4.2 & 12.3 & 7.2 & 7.3 & 4.3 & 6.4 & 4.1 & 7.3 & 11.7 & 3.9 & 10.3 \\
\hline Iso- $\mathrm{C}_{17: 0}$ & 1.5 & 7.2 & 2.0 & 6.3 & 5.6 & 0.9 & 0.8 & 6.3 & $\operatorname{tr}$ & 10.1 & 1.8 \\
\hline Anteiso- $\mathrm{C}_{17: 0}$ & 15.9 & 15.4 & 23.9 & 24.9 & 8.5 & 11.1 & 12.1 & 24.9 & 19.5 & 9.21 & 16.1 \\
\hline
\end{tabular}




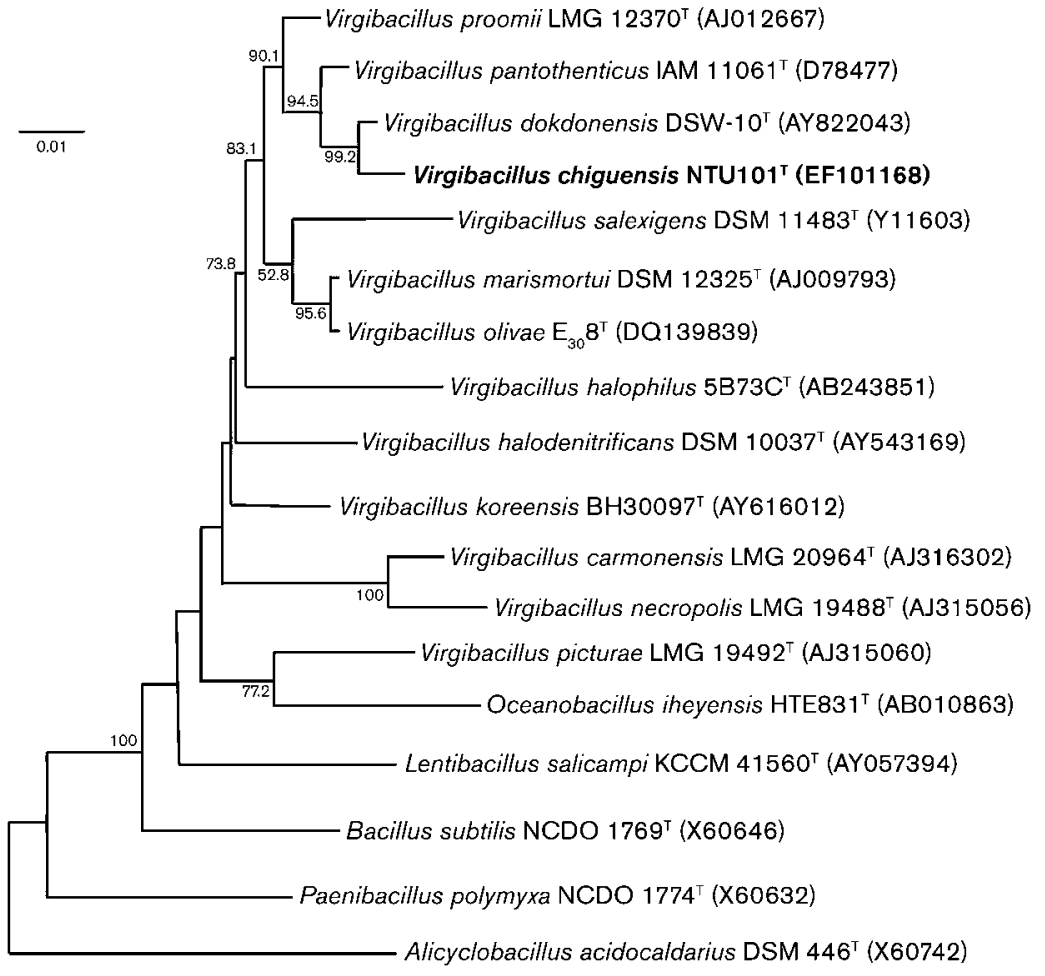

Fig. 1. Neighbour-joining tree showing phylogenetic topology of strain $\mathrm{NTU}-101^{\top}$ with other Virgibacillus species and related taxa based on the 16S rRNA gene sequence. Bootstrap values from 1000 resamplings are indicated. for growth is 5-9, with an optimum of 7.5. Growth occurs under aerobic conditions. Nitrate reduction-positive, $\mathrm{H}_{2} \mathrm{~S}$ production-negative. Aesculin, casein and gelatin are hydrolysed. Starch and Tweens 20 and 80 are hydrolysed. Voges-Proskauer reaction is negative. Indole is not produced. Arginine dihydrolase and lysine decarboxylase are absent. When assayed with the API ZYM system, alkaline phosphatase, esterase (C4), esterase lipase (C8), lipase (C14), acid phosphatase, naphthol-AS-BI-phosphohydrolase, $\alpha$-galactosidase, $\beta$-galactosidase and $\alpha$-mannosidase are present, but leucine arylamidase, valine arylamidase, cystine arylamidase, trypsin, $\alpha$-chymotrypsin, $\beta$-glucuronidase, $\alpha$-glucosidase, $\beta$-glucosidase, $N$-acetyl- $\beta$ glucosaminidase and $\alpha$-fucosidase are absent. Acid is produced from D-cellobiose, D-fructose, D-glucose, Dgalactose, D-mannose, D-melibiose, D-ribose, D-sorbitol, sucrose, lactose and maltose. Acid is not produced from Larabinose, D-melezitose, D-raffinose, D-trehalose and Dxylose. The following substrates are utilized: D-glucose, D-fructose, sucrose, D-cellobiose, D-mannose and maltose. $\mathrm{D}$-Trehalose, benzoate, succinate, L-malate, formate and Lglutamate are not utilized. Major polar lipids are diphosphatidylglycerol, phosphatidylethanolamine and phosphatidylglycerol. The cell-wall peptidoglycan contains mesodiaminopimelic acid, and $\mathrm{MK}-7$ is the predominant menaquinone. The major fatty acids are anteiso- $\mathrm{C}_{15: 0}$ $(51.9 \%)$, anteiso- $\mathrm{C}_{17: 0}(15.9 \%)$ and iso- $\mathrm{C}_{15: 0}(12.1 \%)$. The DNA G + C content is $37.3 \mathrm{~mol} \%$.

The type strain, NTU-101 ${ }^{\mathrm{T}}$ (=BCRC $17637^{\mathrm{T}}=\mathrm{CGMCC}$ $1.6496^{\mathrm{T}}$ ), was isolated from Chigu, a disused salt field located in southern Taiwan.

\section{Acknowledgements}

This work was supported by Grants from Council of Agriculture and National Science Council, ROC.

\section{References}

An, S. Y., Asahara, M., Goto, K., Kasai, H. \& Yokota, A. (2007). Virgibacillus halophilus sp. nov., spore-forming bacteria isolated from soil in Japan. Int J Syst Evol Microbiol 57, 1607-1611.

Anton, J., Oren, A., Benlloch, S., Rodriguez-Valera, F., Amann, R. \& Rossello-Mora, R. (2002). Salinibacter ruber gen. nov., sp. nov., a novel, extremely halophilic member of the Bacteria from saltern crystallizer ponds. Int J Syst Evol Microbiol 52, 485-491.

Descheemaeker, P. \& Swings, J. (1995). The application of fatty acid methyl ester analysis (FAME) for the identification of heterotrophic bacteria present in decaying Lede-stone of the St. Bavo Cathedral in Ghent. Sci Total Environ 167, 241-247.

Ezaki, T., Hashimoto, Y. \& Yabuuchi, E. (1989). Fluorometric deoxyribonucleic acid-deoxyribonucleic acid hybridization in microdilution wells as an alternative to membrane filter hybridization in which radioisotopes are used to determine genetic relatedness among bacterial strains. Int J Syst Bacteriol 39, 224-229.

Heyndrickx, M., Lebbe, L., Kersters, K., De Vos, P., Forsyth, G. \& Logan, N. A. (1998). Virgibacillus: a new genus to accommodate Bacillus pantothenticus (Proom and Knight 1950). Emended description of Virgibacillus pantothenticus. Int J Syst Bacteriol 48, 99-106.

Heyndrickx, M., Lebbe, L., Kersters, K., Hoste, B., De Wachter, R., De Vos, P., Forsyth, G. \& Logan, N. A. (1999). Proposal of Virgibacillus proomii sp. nov. and emended description of Virgibacillus pantothenticus (Proom and Knight 1950) Heyndrickx et al. 1998. Int J Syst Bacteriol 49, 1083-1090. 
Heyrman, J., Mergaert, J., Denys, R. \& Swings, J. (1999). The use of fatty acid methyl ester analysis (FAME) for the identification of heterotrophic bacteria present on three mural paintings showing severe damage by microorganisms. FEMS Microbiol Lett 181, 55-62.

Heyrman, J., Logan, N. A., Busse, H.-J., Balcaen, A., Lebbe, L., Rodriguez-Diaz, M., Swings, J. \& De Vos, P. (2003). Virgibacillus carmonensis sp. nov., Virgibacillus necropolis sp. nov. and Virgibacillus picturae sp. nov., three novel species isolated from deteriorated mural paintings, transfer of the species of the genus Salibacillus to Virgibacillus, as Virgibacillus marismortui comb. nov. and Virgibacillus salexigens comb. nov., and emended description of the genus Virgibacillus. Int J Syst Evol Microbiol 53, 501-511.

Komagata, K. \& Suzuki, K. (1987). Lipid and cell-wall analysis in bacterial systematics. Methods Microbiol 19, 161-207.

Lee, J. S., Lim, J. M., Lee, K. C., Lee, J. C., Park, Y. H. \& Kim, C. J. (2006). Virgibacillus koreensis sp. nov., a novel bacterium from a salt field, and transfer of Virgibacillus picturae to the genus Oceanobacillus as Oceanobacillus picturae comb. nov. with emended descriptions. Int J Syst Evol Microbiol 56, 251-257.

Mesbah, M., Premachandran, U. \& Whitman, W. B. (1989). Precise measurement of the $\mathrm{G}+\mathrm{C}$ content of deoxyribonucleic acid by highperformance liquid chromatography. Int J Syst Bacteriol 39, 159-167.
Quesada, T., Aguilera, M., Morillo, J. A., Ramos-Cormenzana, A. \& Monteoliva-Sánchez, M. (2007). Virgibacillus olivae sp. nov., isolated from waste wash-water from processing of Spanish-style green olives. Int J Syst Evol Microbiol 57, 906-910.

Shin, Y. K., Lee, J.-S., Chun, C. O., Kim, H.-J. \& Park, Y.-H. (1996). Isoprenoid quinone profiles of the Leclercia adecarboxylata KCTC $1036^{\mathrm{T}}$. J Microbiol Biotechnol 6, 68-69.

Stackebrandt, E. \& Liesack, W. (1993). Nucleic acids and classification. In Handbook of New Bacterial Systematics, pp. 152-189. Edited by M. Goodfellow \& A. G. O’Donnell. London: Academic Press.

Thompson, J. D., Higgins, D. G. \& Gibson, T. J. (1994). CLUSTAL W: improving the sensitivity of progressive multiple sequence alignment through sequence weighting, position-specific gap penalties and weight matrix choice. Nucleic Acids Res 22, 4673-4680.

Yoon, J. H., Oh, T. K. \& Park, Y. H. (2004). Transfer of Bacillus halodenitrificans Denariaz et al. 1989 to the genus Virgibacillus as Virgibacillus halodenitrificans comb. nov. Int J Syst Evol Microbiol 54, 2163-2167.

Yoon, J. H., Kang, S. J., Lee, S. Y., Lee, M. H. \& Oh, T. K. (2005). Virgibacillus dokdonensis sp. nov., isolated from a Korean island, Dokdo, located at the edge of the East Sea in Korea. Int J Syst Evol Microbiol 55, 1833-1837. 